\title{
CHARACTERIZATION AND FRACTIONATION OF PHOSPHORUS USING SEQUENTIAL EXTRACTION FROM MARINE SEDIMENT OF JAKARTA BAY
}

\author{
Budiawan $^{1}$, Askal Maimulyanti ${ }^{2}$, , Asep Saefumillah ${ }^{1}$ and Heny Suseno ${ }^{3}$ \\ ${ }^{1}$ Department of Chemistry, Faculty of Mathematics and Natural Sciences, \\ Universitas Indonesia, Indonesia \\ ${ }^{2}$ Department of Analytical Chemistry, Politeknik AKA Bogor, Indonesia \\ ${ }^{3}$ Marine Radiology Group, Center for Technology and Meterology, National Nuclear Energy \\ Agency, Indonesia \\ ${ }^{\circledR}$ Corresponding Author: askal_m@yahoo.com
}

\begin{abstract}
Characterization and fractionation of phosphorus $(\mathrm{P})$ in the marine sediment of Jakarta Bay were investigated in this study. IR spectroscopy resulted from the main peaks at the wavenumber were $900-1500 \mathrm{~cm}^{-1}$ indicates the minerals, oxide, and phosphates. Physicochemical with pH (5.8-6.7), lost on ignition (11.73-16.03 \%), Fe content (8.40-59.12 $\mathrm{mg} / \mathrm{g})$, Mn content $(0.17-1.38 \mathrm{mg} / \mathrm{g})$, Ca content $(0.01-8.25 \mathrm{mg} / \mathrm{g})$ and total phosphorus $(8.73-994.72 \mu \mathrm{g} / \mathrm{g})$. Fractionation of phosphate using sequential extraction resulted in water-soluble $\mathrm{P}\left(\mathrm{H}_{2} \mathrm{O}-\mathrm{P}\right)$ of $0.27-0.76 \mu \mathrm{g} / \mathrm{g}$, loosely bound-P $\left(\mathrm{NH}_{4} \mathrm{Cl}-\mathrm{P}\right)$ of $0.54-2.27 \mu \mathrm{g} / \mathrm{g}$, exchangeable fraction- $\mathrm{P}\left(\mathrm{NaHCO}_{3}-\mathrm{P}\right)$ of 3.53-9.69 $\mu \mathrm{g} / \mathrm{g}, \mathrm{P}$ bound to Fe $(\mathrm{NaOH}-$ $\mathrm{P})$ of $1.63-11.23 \mu \mathrm{g} / \mathrm{g}$ and $\mathrm{P}$ bound to $\mathrm{Ca}(\mathrm{HCl}-\mathrm{P})$ of $1.20-2.21 \mu \mathrm{g} / \mathrm{g}$. The linear correlation between Mn content in sediment to $\mathrm{HCl}-\mathrm{P}$ fraction with $\mathrm{R}^{2}=0.9126$ and between calcium content in sediment to HCl-P fraction with $\mathrm{R}^{2}=$ 0.8476
\end{abstract}

Keywords: Jakarta Bay, Marine Sediment, Phosphorus, Sequential Extraction.

RASĀYAN J. Chem., Vol. 14, No.3, 2021

\section{INTRODUCTION}

Phosphorus is an important nutrient in both marine and freshwater ecosystems for the phosphorus cycle in marine environments. ${ }^{1}$ Many pollutants are accumulated to sediment in the river, marine, or lake. The phosphorus can pollute the water into the sediment with a chemical reaction such as adsorption and precipitation. ${ }^{2}$ Phosphorus has a strong association with particulate matter in the water system, both inorganic and organic forms which commonly occur. The chemical characterization of sediment is necessary for predicting the phosphorus exchange between water and sediment. ${ }^{3-7}$

The method for separation and determination of phosphorus content in marine sediment is the sequential extraction method. ${ }^{8}$ This method has the advantages of simple operation, easily accessible reagent, and less interference between various form. ${ }^{9}$ The concentration of phosphorus fractions from sequential extractions was used to describe different forms of phosphorus in the sediment. ${ }^{10}$ Phosphorus in marine sediment was fractionated using a sequential extraction scheme such as extraction using $\mathrm{NH}_{4} \mathrm{Cl}, \mathrm{NaOH}$, and $\mathrm{HCl}^{1{ }^{11}}$ Some of the studies about fractionation phosphorus include sediment from river ${ }^{12}$ and sediment from lakes. ${ }^{13-15}$ Limited study about characteristics and fractionation phosphorus from marine sediment. The objective of this study is to explore the characteristics and fractionation of phosphorus in marine sediment from Jakarta Bay and to give information about relationships between phosphorus form and sediment characterization in the marine environment.

\section{Materials}

\section{EXPERIMENTAL}

The reagent used in this research was from Merck with an analytical grade. $\mathrm{KH}_{2} \mathrm{PO}_{4}, \mathrm{NH}_{4} \mathrm{Cl}(1.0 \mathrm{M})$, $\mathrm{NaHCO}_{3}(0.5 \mathrm{M}), \mathrm{NaOH}(2 \mathrm{M}), \mathrm{HCl}(0.5 \mathrm{M})$, and aqua distillation.

Rasayan J. Chem., 14(3), 1544-1550(2021)

http://doi.org/10.31788/ RJC.2021.1436050 
RASĀYAN J. Chem.

Vol. 14 | No. 3 |1544-1550| July - September | 2021

\section{Sediment Sampling}

Sediment samples were obtained from Jakarta Bay, Indonesia. Location of study with six station were station $1\left(106^{\circ} 32^{\prime} 17.6^{\prime \prime} \mathrm{E}, 06^{\circ} 00^{\prime} 47.3^{\prime \prime} \mathrm{S}\right)$, station $2\left(106^{\circ} 33^{\prime} 29.8^{\prime \prime} \mathrm{E}, 06^{\circ} 00^{\prime} 51.0^{\prime \prime} \mathrm{S}\right)$ station $3\left(106^{\circ}\right.$ 34' 32.6” E, $\left.06^{\circ} 01^{\prime} 24.2^{\prime \prime} \mathrm{S}\right)$, station 4 (106 34' 45.6” E. 06 00' 55.2” S), station 5 (106 35' 48.3" E, $\left.06^{\circ} 00^{\prime} 51.6^{\prime \prime} \mathrm{S}\right)$ and station 6 (106 37.6' 44.3” E, 06 00' 26.6” S).

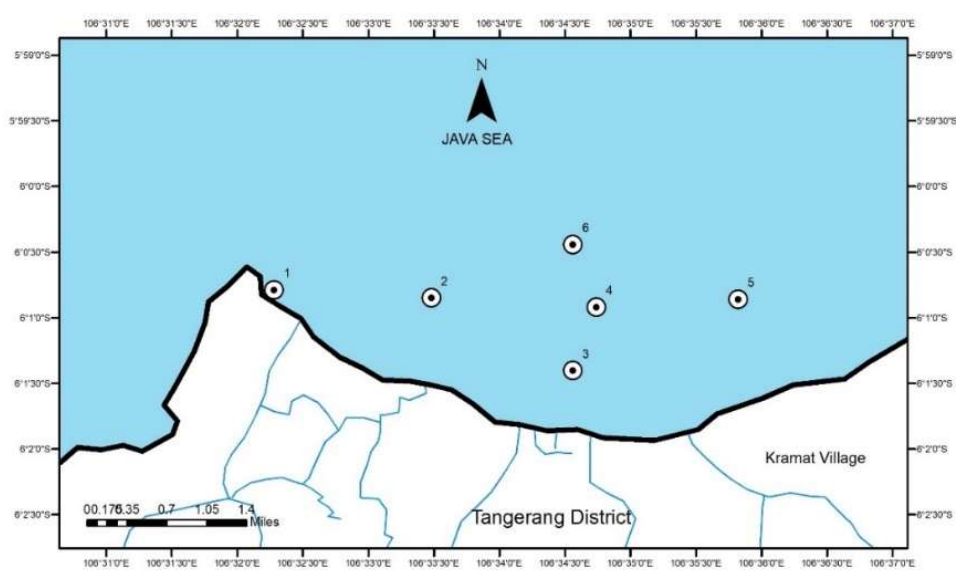

Fig.-1: Geographical Position of Studied Area in Jakarta Bay

\section{Infra-Red Analysis}

Characterization of a functional group from sediment used the infrared analysis method. FTIR analysis was used for the identification of the functional group of sediment including organic and inorganic compounds.

\section{Chemical Characterization.}

The measurement of $\mathrm{pH}$ was carried out in suspensions formed with distillation water. Nitric acid and perchloric acid were used in the digestion process. The determination of $\mathrm{Fe}, \mathrm{Mn}$, and $\mathrm{Ca}$ content using atomic absorption spectrometry.

\section{Fractionation of Phosphorus}

The phosphorus form in the sample was separated by sequential extraction. The first extraction used $\mathrm{H}_{2} \mathrm{O}$ as solvent. The next extraction used $\mathrm{NH}_{4} \mathrm{Cl}(1.0 \mathrm{M}), \mathrm{NaHCO}_{3}(0.5 \mathrm{M}), \mathrm{NaOH}(2 \mathrm{M})$, and $\mathrm{HCl}(0.5 \mathrm{M})$. The phosphorus concentration was measured using a UV-Vis spectrometer at $891 \mathrm{~nm}$.

\section{Sediment Characterization.}

\section{RESULTS AND DISCUSSION}

Sediment from six stations (S1, S2, S3, S4, S5, S6) was used in this study. Functional group analysis was done to know the active group of sediment by using spectroscopy infrared spectrum of IR analysis and the peak of wavenumber showed in Fig.-2.

The organic and organic compounds can be identified by FTIR spectroscopy. ${ }^{17}$ The wavenumber of the IR spectrum can be seen in Table-1.

Table-1: Wavenumber of IR Spectrum from Marine Sediment of Jakarta Bay

\begin{tabular}{c|c|c}
\hline Sediment & Location & Wavenumber $\left(\mathrm{cm}^{-1}\right)$ \\
\hline S1 & $106^{\circ} 32^{\prime} 17.6^{\prime \prime} \mathrm{E}, 06^{\circ} 00^{\prime} 47.3^{\prime \prime} \mathrm{S}$ & $1002.7 ; 909.5$ \\
\hline S2 & $106^{\circ} 33^{\prime} 29.8^{\prime \prime} \mathrm{E}, 06^{\circ} 00^{\prime} 51.0^{\prime \prime} \mathrm{S}$ & $1420 ; 1006$ \\
\hline S3 & $106^{\circ} 34^{\prime} 32.6^{\prime \prime} \mathrm{E}, 06^{\circ} 01^{\prime} 24.2^{\prime \prime} \mathrm{S}$ & $3693.8 ; 3623 ; 909.5 ; 998.9$ \\
\hline S4 & $106^{\circ} 34^{\prime} 45.6^{\prime \prime} \mathrm{E}, 06^{\circ} 00^{\prime} 55.2^{\prime \prime} \mathrm{S}$ & $3693.8 ; 3623 ; 1638 ; 909.5 ; 993.9$ \\
\hline S5 & $106^{\circ} 35^{\prime} 48.3^{\prime \prime} \mathrm{E}, 06^{\circ} 00^{\prime} 51.66^{\prime \prime} \mathrm{S}$ & $3693.8 ; 3623 ; 1636.3 ; 905.5 ; 998.9$ \\
\hline S6 & $106^{\circ} 37.6^{\prime} 44.3^{\prime \prime} \mathrm{E}, 06^{\circ} 00^{\prime} 26.6^{\prime \prime} \mathrm{S}$ & $3693 ; 3623 ; 3388 ; 1636 ; 909.5 ; 995.2$ \\
\hline
\end{tabular}


RASĀYAN J. Chem.

Vol. 14 | No. 3 |1544-1550| July - September | 2021
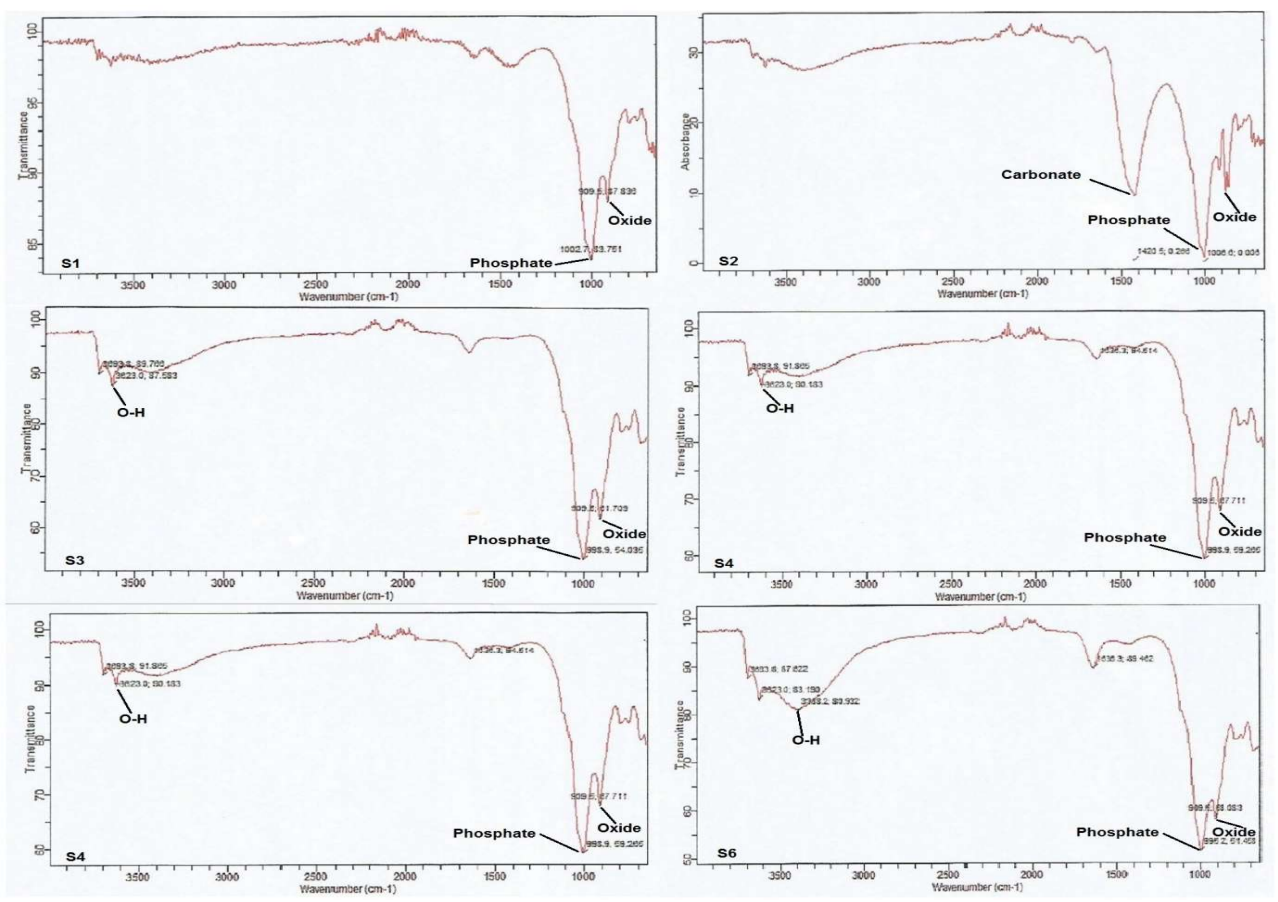

Fig.-2: Infra-Red Spectrum of Sediment

The sediment at each station was coded as S1, S2, S3, S4, S5, and S6. All spectrum showed the peak at $900-1000 \mathrm{~cm}^{-1}$ that indicated fingerprint for metal and minerals. The peak at $1400 \mathrm{~cm}^{-1}$ for carbonates and $683 \mathrm{~cm}^{-1}, 790 \mathrm{~cm}^{-1}, 1009 \mathrm{~cm}^{-1}$ were predicted for silicates dan iron-oxide. ${ }^{18}$ Phosphates usually at $850-1075$ $\mathrm{cm}^{-1}, \mathrm{PO}_{4}{ }^{3-}$ at $1005 \mathrm{~cm}^{-1}$, and mineral geothite-phosphate and $\mathrm{TiO}_{2}$ were present in these peaks. Phosphates as $\mathrm{HPO}_{4}{ }^{2-}$ at peaks of $850 \mathrm{~cm}^{-1}, \mathrm{H}_{2} \mathrm{PO}_{4}^{-}$at peaks of $875 \mathrm{~cm}^{-1}, 940 \mathrm{~cm}^{-1}, 1075 \mathrm{~cm}^{-1} .^{19}$ The IR spectra of $\mathrm{PO}_{4}{ }^{3-}$ , $\mathrm{HPO}_{4}{ }^{2-}, \mathrm{H}_{2} \mathrm{PO}_{4}{ }^{-}$and $\mathrm{H}_{3} \mathrm{PO}_{4}{ }^{2}$ will show the differences peaks. ${ }^{20}$ The dominant species of phosphorus in the sediment is $\mathrm{H}_{2} \mathrm{PO}_{4}^{-}$. The low intensity in $3700-3000 \mathrm{~cm}^{-1}$ indicates the presence of clay minerals. The peak at $3623 \mathrm{~cm}^{-1}$ referred to the $\mathrm{OH}$ stretch of $\mathrm{H}_{2} \mathrm{O} .^{21}$

Spectrum with wavenumber at $110-913 \mathrm{~cm}^{-1}$ was the contributed to Si-O stretching band of kaolinite. Spectrum at a wavenumber of $676-693 \mathrm{~cm}^{-1}$ was the deformation of metal oxide..$^{22,23}$

The physicochemical of marine sediment can be seen in Table- 2 .

Table-2: Physicochemical Analysis of Marine Sediment from Jakarta Bay

\begin{tabular}{c|c|c|c|c|c|c}
\hline Sediment & $\mathrm{pH}$ & $\begin{array}{c}\text { LOI } \\
(\%)\end{array}$ & $\begin{array}{c}\text { Fe content } \\
(\mathrm{mg} / \mathrm{g})\end{array}$ & $\begin{array}{c}\text { Mn content } \\
(\mathrm{mg} / \mathrm{g})\end{array}$ & $\begin{array}{c}\text { Ca content } \\
(\mathrm{mg} / \mathrm{g})\end{array}$ & $\begin{array}{c}\text { Total P } \\
(\mu \mathrm{g} / \mathrm{g})\end{array}$ \\
\hline S 1 & $6.5 \pm 0.1$ & $15.83 \pm 0.24$ & $55.18 \pm 3.57$ & $1.21 \pm 0.11$ & $0.31 \pm 0.26$ & $363.43 \pm 22.20$ \\
\hline S 2 & $6.7 \pm 0.2$ & $12.72 \pm 0.39$ & $8.40 \pm 0.68$ & $0.17 \pm 0.05$ & $8.25 \pm 1.00$ & $21.74 \pm 10.17$ \\
\hline S 3 & $6.0 \pm 0.1$ & $11.76 \pm 0.02$ & $59.12 \pm 1.62$ & $1.51 \pm 0.05$ & $0.01 \pm 0.01$ & $994.72 \pm 13.01$ \\
\hline S 4 & $6.0 \pm 0.1$ & $15.90 \pm 0.06$ & $54.19 \pm 2.62$ & $1.38 \pm 0.02$ & $0.01 \pm 0.00$ & $979.69 \pm 21.36$ \\
\hline S 5 & $5.8 \pm 0.0$ & $11.73 \pm 0.05$ & $57.20 \pm 1.93$ & $1.35 \pm 0.03$ & $0.07 \pm 0.00$ & $24.36 \pm 7.87$ \\
\hline S 6 & $5.9 \pm 0.1$ & $16.03 \pm 0.09$ & $58.33 \pm 0.96$ & $1.36 \pm 0.02$ & $0.04+0.00$ & $316.70 \pm 31.12$ \\
\hline
\end{tabular}

The $\mathrm{pH}$ range of sediment was found from 5.8 to 6.7. The effect of $\mathrm{pH}$ on total phosphorus showed that the acid condition can increase the total phosphorus. The $\mathrm{H}_{2} \mathrm{PO}_{4}^{-}$species at $\mathrm{pH}$ 2-7 and $\mathrm{HPO}_{4}{ }^{2-}$ species are present in the $\mathrm{pH}$ region between 7 and 11 . The $\mathrm{pH}$ higher than 12 the concentration of $\mathrm{PO}_{4}{ }^{3-}$ species becomes. Organic matter was measured as a loss of ignition $\left(550^{\circ} \mathrm{C}\right.$ for 4 hours $)$. The LOI indicated the organic component in the sediment.

The result showed that Fe in sediment ranged from 8.40 to $59.12 \mathrm{mg} / \mathrm{g}$. The highest iron content was found in station 6 and the lowest iron content at station 2 was $8.40 \mathrm{mg} / \mathrm{g}$. Manganese content were $0.17 \mathrm{mg} / \mathrm{g}$ - 
RASĀYAN J. Chem.

Vol. 14 | No. 3 |1544-1550| July - September | 2021

$1.38 \mathrm{mg} / \mathrm{g}$. The highest manganese content was at station 4 was 1.38 and the lowest at station 2. Calcium was analyzed $0.01-8.25 \mathrm{mg} / \mathrm{g}$. The highest calcium content was at station 2 .

The total phosphorus concentration of sediment samples was $21.74-994.72 \mu \mathrm{g} / \mathrm{g}$ (dry weight). The highest TP was found at station 4 and the lowest Total $P$ was at station 2. Increasing total phosphorus at the sediment has been related to eutrophication. ${ }^{24-29}$

Fractionation of Phosphorus in Marine sediment

Fractionation of phosphorus in marine sediment used a sequential extraction method. The fractionation of phosphorus can be seen in Table-3.

Table-3: Fractionation of Phosphorus

\begin{tabular}{c|c|c|c|c|c}
\hline Sediment & $\mathrm{H}_{2} \mathrm{O}-\mathrm{P}(\mu \mathrm{g} / \mathrm{g})$ & $\mathrm{NH}_{4} \mathrm{Cl}-\mathrm{P}(\mu \mathrm{g} / \mathrm{g})$ & $\mathrm{NaHCO}_{3}-\mathrm{P}(\mu \mathrm{g} / \mathrm{g})$ & $\mathrm{NaOH}-\mathrm{P}(\mu \mathrm{g} / \mathrm{g})$ & $\mathrm{HCl}-\mathrm{P}(\mu \mathrm{g} / \mathrm{g})$ \\
\hline $\mathrm{S}$ 1 & $0.76 \pm 0.43$ & $0.92 \pm 0.07$ & $6.49 \pm 0.84$ & $3.29 \pm 0.09$ & $2.19 \pm 0.58$ \\
\hline $\mathrm{S}$ 2 & $0.27 \pm 0.02$ & $2.27 \pm 0.04$ & $9.69 \pm 0.12$ & $1.63 \pm 0.37$ & $2.21 \pm 0.23$ \\
\hline $\mathrm{S} 3$ & $0.45 \pm 0.07$ & $0.99 \pm 0.20$ & $5.19 \pm 0.73$ & $9.78 \pm 0.26$ & $1.20 \pm 0.07$ \\
\hline $\mathrm{S} 4$ & $0.44 \pm 0.20$ & $0.75 \pm 0.03$ & $7.36 \pm 0.32$ & $6.95 \pm 0.95$ & $1.33 \pm 0.26$ \\
\hline S 5 & $0.27 \pm 0.06$ & $0.62 \pm 0.33$ & $3.53 \pm 0.09$ & $11.23 \pm 0.14$ & $1.91 \pm 0.21$ \\
\hline S 6 & $0.30 \pm 0.08$ & $0.54 \pm 0.10$ & $5.12 \pm 0.37$ & $7.92 \pm 0.76$ & $1.88 \pm 0.03$ \\
\hline
\end{tabular}

Speciation of inorganic $\mathrm{P}$ was carried out using the method on sequential extraction procedure which divided inorganic P-fraction in a sediment into water-soluble $\mathrm{P}\left(\mathrm{H}_{2} \mathrm{O}-\mathrm{P}\right)$, loosely bound-P $\left(\mathrm{NH}_{4} \mathrm{Cl}-\mathrm{P}\right)$, exchangeable fraction- $\mathrm{P}\left(\mathrm{NaHCO}_{3}-\mathrm{P}\right)$, $\mathrm{P}$ bound to iron (NaOH-P), $\mathrm{P}$ bound to calcium (HCl-P). Phosphorus content in $\mathrm{H}_{2} \mathrm{O}(0.27-0.76 \mu \mathrm{g} / \mathrm{g}), \mathrm{NH}_{4} \mathrm{Cl}(0.54-2.27 \mu \mathrm{g} / \mathrm{g}), \mathrm{NaHCO}_{3}(3.53-9.69 \mu \mathrm{g} / \mathrm{g}), \mathrm{NaOH}(1.63-11.23$ $\mu \mathrm{g} / \mathrm{g})$ and $\mathrm{HCl}(1.20-2.21 \mu \mathrm{g} / \mathrm{g})$ from six stations. Stations 1,2 , and 4 indicated the highest fraction as P$\mathrm{NaHCO}_{3}$ (exchangeable fraction) with content $6.49 \mu \mathrm{g} / \mathrm{g}, 9,69 \mu \mathrm{g} / \mathrm{g}$, and $7.36 \mu \mathrm{g} / \mathrm{g}$ respectively. Sediment at stations 3, 5, and 6 was the highest component was extracted by $\mathrm{NaOH}$ with content were $9.78 \mu \mathrm{g} / \mathrm{g}$, $11.23 \mu \mathrm{g} / \mathrm{g}$, and $7.92 \mu \mathrm{g} / \mathrm{g}$. The knowledge of the chemical speciation of phosphorus is important to known the biogeochemical of phosphorus in the ocean. ${ }^{30}$ The relationship of Mn content with phosphorus fractionations from sediment of Jakarta Bay can be seen in Fig.-3
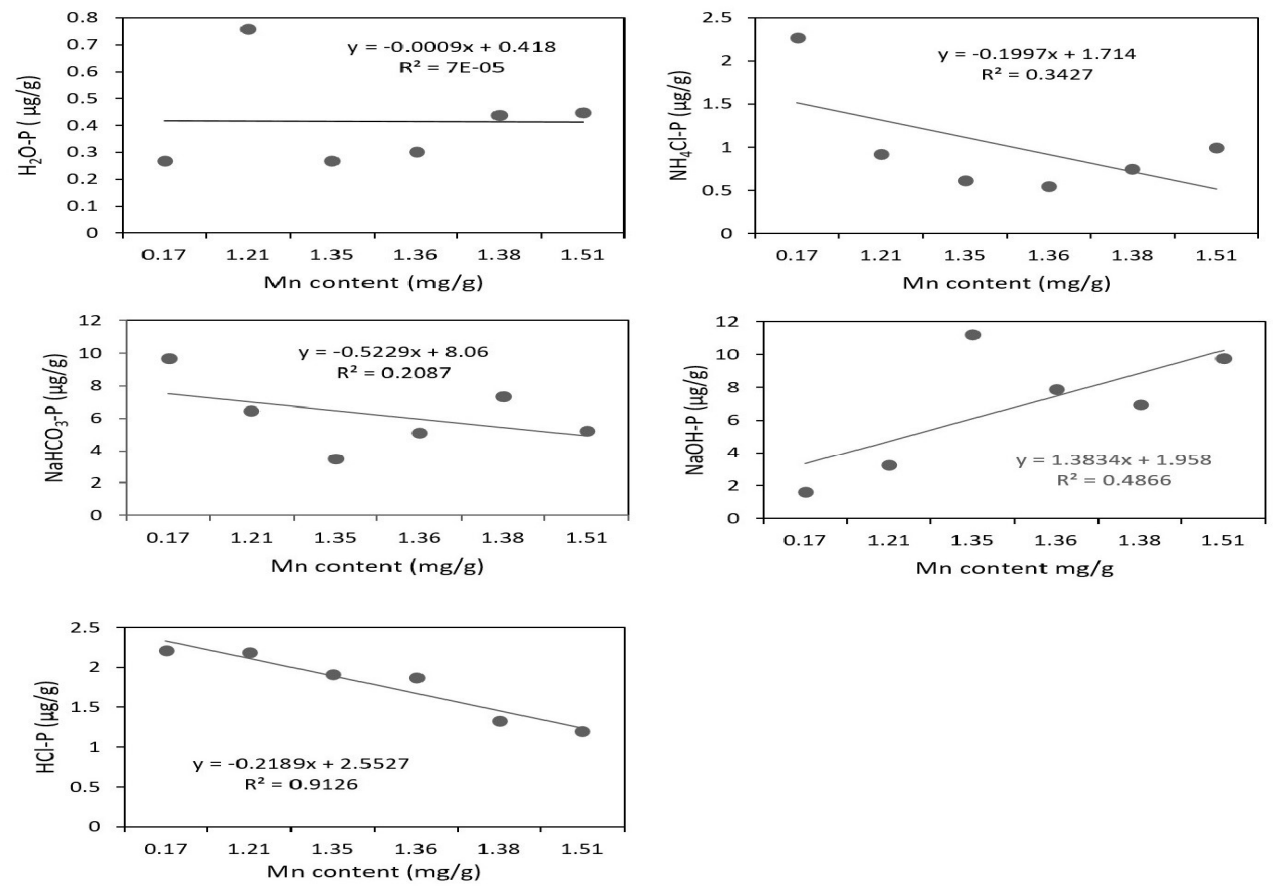

Fig.-3: Relationship between Mn Content with Phosphorus Fractionations 
RASĀYAN J. Chem.

Vol. 14 | No. 3 |1544-1550| July - September | 2021

Figure-3 showed the relationship between Mn content with phosphorus fractionation in the samples. There was no correlation between $\mathrm{Mn}$ content with $\mathrm{H}_{2} \mathrm{O}-\mathrm{P}$ and $\mathrm{NaHCO}_{3}-\mathrm{P}$. Mn content showed a negative correlation to the $\mathrm{NH}_{4} \mathrm{Cl}-\mathrm{P}$ fraction. This indicated that the greater $\mathrm{Mn}$ content in sediment affected the smaller $\mathrm{NH}_{4} \mathrm{Cl}-\mathrm{P}$ fraction. A negative correlation also showed the relationship of $\mathrm{Mn}$ content with HCl-P. It showed a linear correlation with an $\mathrm{R}^{2}$ value was 0.9126 and a regression linear of $0.2189 \mathrm{x}+2.5527$. The $\mathrm{HCl}-\mathrm{P}$ fraction indicated Ca-bound phosphorus but this value is also influenced by Mn content. The larger Mn content affected the smaller calcium-bound phosphorus was found in sediment. The result indicated no correlation between $\mathrm{Mn}$ content with $\mathrm{H}_{2} \mathrm{O}-\mathrm{P}$ and $\mathrm{NaHCO}_{3}-\mathrm{P}$ and a negative correlation between the $\mathrm{NH}_{4} \mathrm{Cl}-$ $\mathrm{P}$ fraction and HCl-P. It happened because the Mn was an unstable ion. Mn can be found as Mn(II) and $\mathrm{Mn}(\mathrm{IV})$. The form of Mn depending on the $\mathrm{pH}$ of the solution was generated from each solvent.

The relationship of Fe content with phosphorus fractionations from the sediment of Jakarta Bay can be seen in Fig.-4.
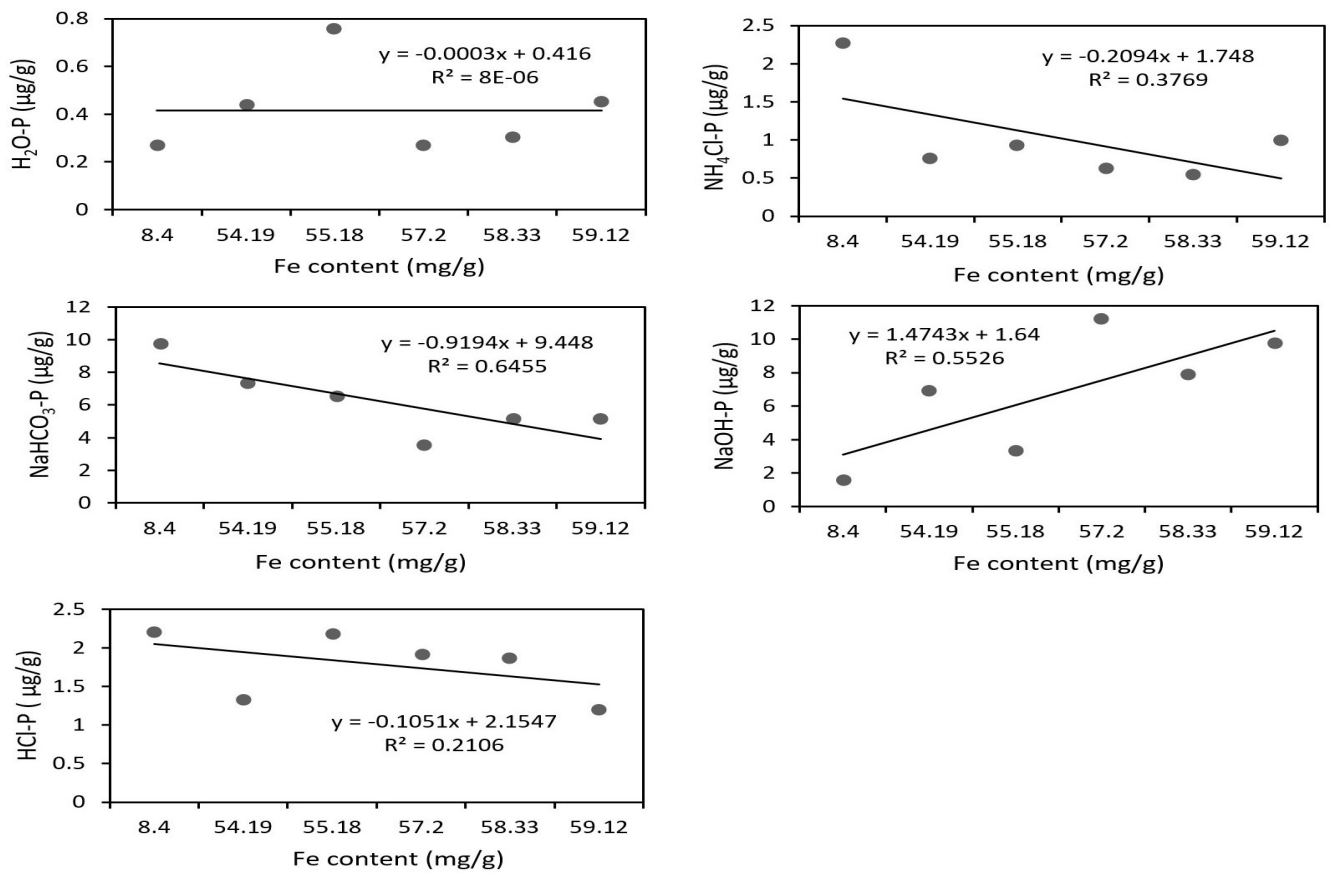

Fig.-4: Relationship of Fe Content with Phosphorus Fractionations

Characteristics of phosphorus can be determined from iron and calcium content. It can predict $\mathrm{P}$ behavior and estimate the potential risk for eutrophication and environmental condition. From Fig.-4 it can be seen there is no correlation between Fe Content with the fractionation of phosphorus. It happened because the $\mathrm{Fe}$ was an unstable ion. Fe can exchange from Fe(II) to Fe(III) .which is influenced by the environmental conditions.

The relationship of Ca content with phosphorus fractionations from the sediment of Jakarta Bay can be seen in Fig.-5.

Linear correlation can be found in the relationship between Ca content with the HCl-P fraction with $\mathrm{R}^{2}$ value was 0.8476 and regression linear equation was $0.207 \mathrm{x}+1.283$. The correlation of Ca content to $\mathrm{HCl}-$ $\mathrm{P}$ fraction indicated if the sediment has the rich of calcium showed the high $\mathrm{HCl}-\mathrm{P}$ fraction (calcium bound to phosphate).

\section{CONCLUSION}

Characteristics of marine sediment of Jakarta Bay in six stations were characterized by IR spectroscopy, physicochemical properties, and fractionation of phosphorus by sequential extraction. The relationship of metal content to phosphorus fractionation showed that there is no correlation between $\mathrm{Fe}, \mathrm{Mn}$ and $\mathrm{Ca}$ content against total phosphorus in the marine sediment of Jakarta Bay. There was a linear correlation between Mn content in sediment to $\mathrm{HCl}-\mathrm{P}$ fraction showed by $\mathrm{R}^{2}$ value was 0.9126 and regression linear 
RASĀYAN J. Chem.

Vol. 14 | No. 3 |1544-1550| July - September | 2021

was $0.2189 x+2.5527$ The curve obtained a negative correlation. A linear correlation between calcium content in sediment to the HCl-P fraction with the $\mathrm{R}^{2}$ value of 0.8476 and regression linear was $0.207 \mathrm{x}+$ 1,283 and the curve showed a positive correlation.
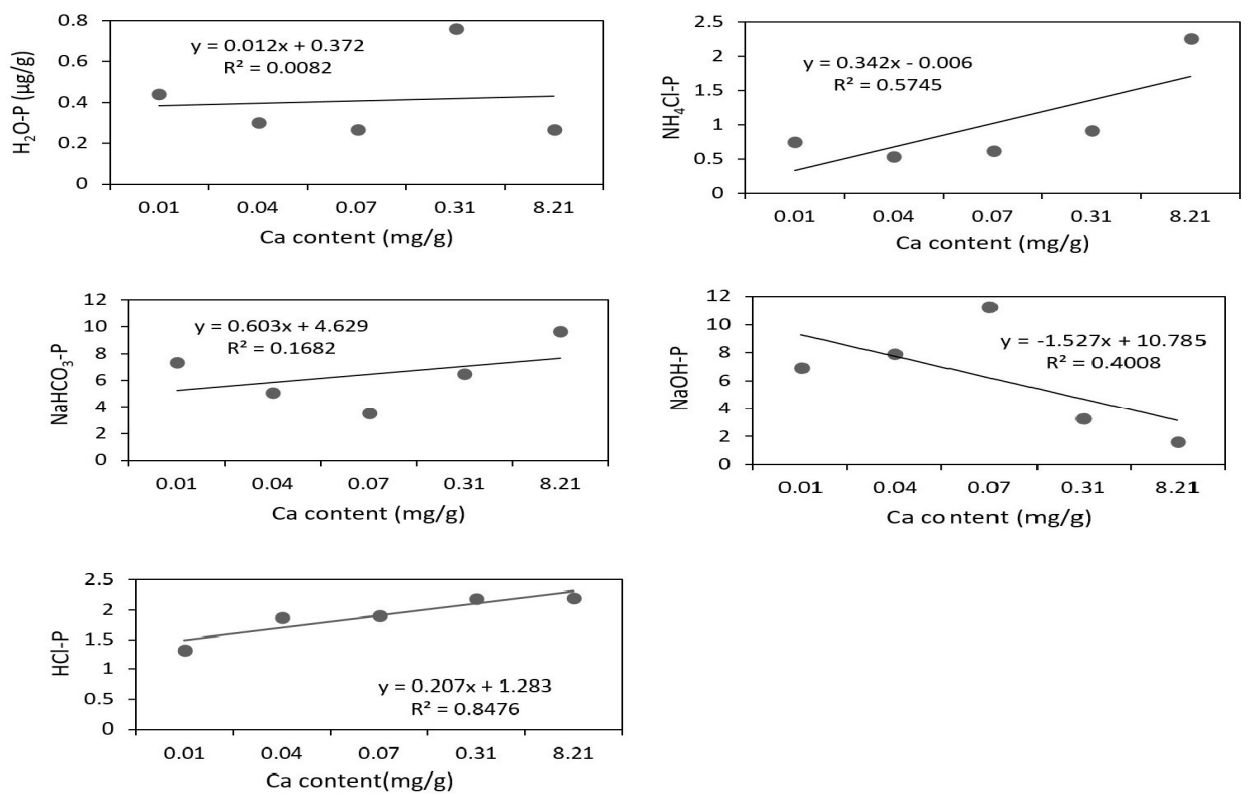

Fig.-5: Relationship Between Ca Content with Phosphorous Fractionations

\section{ACKNOWLEDGEMENT}

This research was funded by the Ministry of Industry, Indonesia. Thanks for the financial support.

\section{REFERENCES}

1. H.Y. Chen, T.H. Fang, M.R. Preston and S. Lin, Atmospheric Environment, 40(2), 279(2006), https://doi.org/10.1016/j.atmosenv.2005.09.051

2. L.H. Kim, E. Choi and M.K. Stenstrom, Chemosphere, 50(1), 53(2003), https://doi.org/10.1016/S0045$\underline{6535(02) 00310-7}$

3. I. Aydin, F. Aydin, A. Saydut and C. Hamamci, Journal of Hazardous Materials, 168(2-3), 664(2009), https://doi.org/10.1016/j.jhazmat.2009.02.095

4. Y. Sahin, A. Demirak and F. Keskin, Lakes, Reserviors and Ponds, 6(2), 139(2012).

5. N. Zaaboub, A. Ounis, M.A, Helali, B. Béjaoui, A.I. Lillebø, E.F. Silva and L. Aleya, Ecological Engineering, 73, 115(2014), https://doi.org/10.1016/j.ecoleng.2014.09.017

6. J. Meng, P. Yao, Z. Yu, T.S. Bianchi, B. Zhao, H. Pan and D. Li, Estuarine, Coastal and Shelf Science, 144, 27(2014), https://doi.org/10.1016/j.ecss.2014.04.015

7. H. Wang, A. Appan and J.S. Gulliver, Water Research, 37(16), 3928(2003), https://doi.org/10.1016/S0043-1354(03)00304-X

8. K. C. Ruttenberg, Limnology and Oceanography, 37(7), 1460(1992), https://doi.org/10.4319/lo.1992.37.7.1460

9. B. Shan, J. Li, W. Zhang, Z. Di and X. Jin, Ecological Engineering, 97, 426(2016), https://doi.org/10.1016/j.ecoleng.2016.10.042

10. Q. Liu, S. Liu, H. Zhao, L. Deng, C. Wang, Q. Zhao and S. Dong, Chemosphere, 120, 653(2015), https://doi.org/10.1016/j.chemosphere.2014.10.012

11. H.S. Jensen, P. Kristensen, E. Jeppesen, A. Skytthe, Hydrobiologia, 235(1), 731(1992), https://doi.org/10.1007/978-94-011-2783-7 66

12. S. Sun, S. Huang, X. Sun, W. Wen, Journal of Environmental Sciences, 21(3), 291(2009), https://doi.org/10.1016/S1001-0742(08)62266-4 
RASĀYAN J. Chem.

Vol. 14 | No. 3 |1544-1550| July - September | 2021

13. X, Ding, M. Behbahani, C. Gruden, and Y. Seo, Journal of Environmental Management, 160, 193(2015), https://doi.org/10.1016/j.jenvman.2015.06.010

14. A. Kaiserli, D. Voutsa and C. Samara, Chemosphere, 46(8), 1147(2002), https://doi.org/10.1016/S0045-6535(01)00242-9

15. S. Wang, X. Jin, H. Zhao, X. Zhou and F. Wu, Colloids and Surfaces A: Physicochemical and Engineering Aspects, 297(1-3), 154(2007), https://doi.org/10.1016/j.colsurfa.2006.10.040

16. W.A. House and F.H. Denison, The Science of the Total Environment 282, 341(2002), https://doi.org/10.1016/S0048-9697(01)00923-8

17. S. Veerasingam and R Venkatachalapathy, Infrared Physics and Technology, 66, 136(2014), https://doi.org/10.1016/j.infrared.2014.06.005

18. S. Azzouz and C. Boukhalfa, (2012). Procedia Engineering, 33, 121(2012), https://doi.org/10.1016/j.proeng.2012.01.1184

19. G. Lefèvre, Advances in Colloid and Interface Science, 107(2-3), 109(2004), https://doi.org/10.1016/j.cis.2003.11.002

20. E.J. Elzinga and D.L. Sparks, Journal of Colloid and Interface Science, 308(1), 53(2007), https://doi.org/10.1016/j.jcis.2006.12.061

21. H. Langford, A. Hodson and S. Banwart, Applied Geochemistry, 26, 206(2011), https://doi.org/10.1016/j.apgeochem.2011.03.105

22. F.K. Abdel-Gawad, H.S Ibrahim, N.S Ammar and M. Ibrahim, Spectrochimica Acta - Part A: Molecular and Biomolecular Spectroscopy, 97, 771(2012), https://doi.org/10.1016/j.saa.2012.07.050

23. P.G. Hatcher, A. Ravin, F. Behar, F. Baudin, Organic Geochemistry, 75, 8(2014), https://doi.org/10.1016/j.orggeochem.2014.05.016

24. S.G. Tuncel, S. Tugrul, T. Topal, Water Research, 41(2), 365(2007), https://doi.org/10.1016/j.watres.2006.10.001

25. A. Avilés, F.X. Niell, Estuarine, Coastal and Shelf Science, 64(4), 786(2005), https://doi.org/10.1016/j.ecss.2005.05.002

26. J. Buanuam, M. Miró, E.H Hansen, J. Shiowatana, J.M. Estela and V. Cerdà, Talanta, 71(4), 1710(2007), https://doi.org/10.1016/j.talanta.2006.08.007

27. B. Gunduz, F. Aydin, I. Aydin and C. Hamamci, Microchemical Journal, 98(1), 72(2011), https://doi.org/10.1016/j.microc.2010.11.006

28. C. Liu, J. Sui and Z.Y. Wang, International Journal of Sediment Research, 23(1), 44(2008), https://doi.org/10.1016/S1001-6279(08)60004-9

29. M. Cong, T. Jiang, Y. Qi, Zao, H. Dong, P. Teng, D. Qiang, and S. Lu, International Journal of Sediment Research, 29(2), 278(2014), https://doi.org/10.1016/S1001-6279(14)60043-3

30. J. Ni, P. Lin, Y. Zhen, X. Yao, L. Guo, Deep Sea Research Part I: Oceanographic Research Papers 105, 74(2015), https://doi.org/10.1016/j.dsr.2015.08.008

[RJC-6050/2020] 